\title{
Nanocalcium sulfate and collagen biomaterials: Effects on osteoblastic cells
}

\author{
Tyler Laurel ${ }^{1}$, Mally Perelman Karmon ${ }^{1}$, Dinh Nguyen $^{1}$ and Rosemary Dziak*1 \\ ${ }^{1}$ Department of Oral Biology, University at Buffalo School of Dental Medicine, USA
}

\begin{abstract}
Introduction: Guided bone regeneration (GBR) using the principle of guided tissue regeneration (GTR) has been widely demonstrated to be a useful technique for enhancing bone healing in a variety of osseous defects including those in periodontal and peri-implant regions. Placement of a biocompatible membrane to guide desirable cells such as osteoblasts to the appropriate site is a critical step in GBR. Optimization of the process includes the prevention of collapse of the membrane with bone grafting materials that also enhance the growth and differentiation of osteoblastic cells at the desired site. The purpose of this in vitro study was to assess the ability of a nano-sized calcium sulfate product $(\mathrm{nCS})$ to enhance the growth and differentiation of human osteoblastic cells on biocompatible collagen materials commonly used in GBR.

Materials and methods: Human osteoblastic cells were cultured under standard in vitro conditions on collagen materials $\left(\mathrm{HeliPLUG}^{\circledR}\right.$ Collagen, RCM6 $6^{\mathrm{TM}}$, or BioGide ${ }^{\circledR}$ ) with or without a coating of nCS. The growth activity of the cells was evaluated with the MTT assay and differentiation with measurements of alkaline phosphatase and in some cases with an Alizarin Red mineralization assay.

Results and conclusion: $\mathrm{nCS}$ increased the activity of cells incubated on pieces of HeliPLUG ${ }^{\circledR}$ Collagen and RCM6 ${ }^{\mathrm{TM}}$ with nonsignificant effects on the BioGide ${ }^{\circledR}$ response. Alkaline phosphatase activity was increased by the presence of $\mathrm{nCS}$ with all three collagen products tested. Mineralization was assessed with only the HeliPLUG ${ }^{\circledR}$ Collagen material and marked significant effects of the nCS coating was observed. These data suggest that the effectiveness of the collagen biomaterials commonly used clinically can be increased with respect to GBR by the concurrent use of $\mathrm{nCS}$.
\end{abstract}

\begin{abstract}
Abbreviations: nCS: nanocalcium sulfate; guided tissue regeneration: GTR; guided bone regeneration: GBR
\end{abstract}

\section{Introduction}

Bone regeneration of an osseous defect involves a spectrum of different types of connective tissue cells with various rates of migration to the affected site. Based on the principle of guided tissue regeneration (GTR), guided bone regeneration (GBR) can be applied to allow repopulation of bony defects with osteoblastic bone forming cells, while excluding undesirable cells such as gingival epithelial and fibroblastic cells from the same site. GBR, therefore, has been shown to be useful in treatment of various bone defects [1]. The placement of a biocompatible membrane made of substances such as collagen is important to guide the cells to the appropriate site, but it is also critical to insure that this material maintains its original position and does not collapse before the regenerative process is completed. This collapse can be prevented by setting the collagen membrane in a grafting material to support the membrane so that it preserves its original position [1].

There are several types of extracellular matrix materials commercially available to clinical dental practitioners for use in the GTR procedures and wound healing applications. Each material has several advantages and disadvantages for specific treatment modalities due to their particular biomaterial and physical properties. Rakhmatia, et al. discussed in a recent review the benefits and limitations of many of the commercially available membranes for use in dental applications [2].

Calcium sulfate (CS) has been successfully used in its hemihydrate form in medicine and dentistry for many years as a bone grafting material [3]. It is utilized as an osteoconductive scaffold that increases bone regeneration while maintaining space and preventing soft tissue invasion. Calcium sulfate can be used as a bone substitute due to its degradation properties when in vivo it releases calcium ions, leading to formation of calcium phosphate, and a temporary local drop in the $\mathrm{pH}$. As a result, surface demineralization of bone occurs which then results in the release of growth factors such as transforming growth factors and bone morphogenetic proteins that encourage bone growth in the defects [4]. Calcium sulfate is presently being most commonly used as a barrier in guided bone regeneration by physically stopping soft connective tissue from developing into bone, which facilitates bone regeneration via the osteopromotion principle [5,6]. A recent study in a preclinical animal model, provided evidence that CS used together with an extracellular cell matrix (ECM) membrane produces synergistic effects on bone regeneration that were speculated to be due to a stimulation of angiogenesis in the initial phases of the healing process [7].

There has been increasing evidence from a variety of experimental studies that nanosized ceramic-like materials can function as bone graft substitutes because of their excellent osseointegrative properties [8-10].

Correspondence to: Rosemary Dziak, PhD, Professor, Department of Oral Biology, University at Buffalo School of Dental Medicine, 318 Foster Hall, South Campus, Main Street, Buffalo, NY 14206, USA, Tel: 1.716.829.3827, E-mail: rdziak@buffalo.edu

Key words: osteoblasts, guided tissue regeneration, guided bone regeneration, collagen membranes, nanocalcium sulfate

Received: March 23, 2017; Accepted: April 10, 2017; Published: April 13, 2017 
Most recently, a novel nanocalcium sulfate (nCS) material fabricated in our laboratory has been shown to have enhanced physical properties, due to its nanosized particles, for osteoconduction and subsequent bone regeneration [11]. The previous studies with this material have shown that nCS particles have a much higher surface area and superior mechanical strength than the traditional calcium sulfate. These properties allow nCS to serve as an excellent osteoconductive material; safe, biocompatible and a good carrier for growth factors [12].

The purpose of this present study was to evaluate the potential beneficial effects of applying nCS to collagen biomembrane materials in order to enhance osteoblastic cell activity and consequently promote more optimal bone regeneration at the applied site.

\section{Materials and methods}

Human osteoblastic cells were purchased as frozen cultures from ScienCell Research Laboratories (Carlsbad, CA) and grown to confluency in alpha minimum essential medium (MEM) supplemented with $10 \%$ fetal bovine serum and $1 \%$ penicillin (Gibco, Life Technologies, Grand Island, NY). The cells were subcultured for no more than 4 passages before use.

nCS was fabricated from conventional size calcium sulfate according to the cryo-vacuum technique previously developed in our laboratory and patented by U.S Patent 7767226 [12]. The physicalchemical characteristics of this nano-sized material as well as its biocompatibility and osteoconductive properties have been previously reported and described in detail $[11,12]$. Collagen discs (approx. $2 \mathrm{~mm}$ thick and $5 \mathrm{~mm}$ in diameter) were prepared by using a sterile scalpel to cut a commercially available resorbable collagen plug (HeliPLUG ${ }^{\circ}$ Collagen Wound Dressing, Integra ${ }^{\circledR}$ Miltex $\left.^{\oplus}\right)$. The material used is US FDA approved for clinical use, and is collagen type I obtained from bovine Achilles tendon. The collagen discs were tested unmodified or coated with the nCS fabricated in our laboratory [12]. The nCS coating was conducted by applying a standardized amount $(0.01 \mathrm{gms})$ of a mixture of the nCS and $20 \mu \mathrm{L}$ of distilled water. nCS discs of comparable size as the collagen ones were fabricated by allowing the nCS paste to harden in a mold made of polyvinylsiloxane. All discs were sterilized immediately before initiation of the cell incubations by radiofrequency-stimulated argon gas plasma (glow discharge) for 10 minutes.

The prepared discs were placed in 96 well tissue culture plates and covered with an appropriate amount of osteoblastic cell suspension (approximately 50,000 cells/200 $\mu \mathrm{L}$ MEM media). Controls were the same of amount of cell suspension without any added collagen discs added to the wells. Unless otherwise indicated, the culture plates were incubated in a $5 \% \mathrm{CO}_{2}$ incubator at $37^{\circ} \mathrm{C}$ for 48 or 96 hours.

Similar procedures were conducted with two other types of resorbable collagen membranes, both commercially available for clinical use. One of these was composed of collagen type 1 of a bovine origin, $\mathrm{RCM}^{\mathrm{Tn}}, 0.3 \mathrm{~mm}$ thick (ACE Surgical Supply Company, Inc. MA, USA) cut for our experiments with a biopsy punch into $5 \mathrm{~mm}$ diameter membranes. The other type of membrane used here was BioGide collagen membrane (GEISTLICH PHARMA AG, Wolhusen, Switzerland), cut by us into $5 \mathrm{~mm}$ diameter circles. This membrane is a bilayer composed of both types I and III collagen of porcine origin. It was among the first materials approved specifically for use in GBR procedures and because of its elasticity is best used in combination with a bone graft material [13]. In this present study, both the RCM6 ${ }^{\mathrm{TM}}$ and BioGide ${ }^{\star}$ membranes were coated with nCS applied on their rough sides.

\section{Tetrazolium salt (MTT) assay}

This assay was used to measure osteoblastic cell activity. After incubation of the cells under the appropriate conditions of either no disc, collagen alone disc, collagen $+\mathrm{nCS}$ or nCS alone disc, for a defined experimental period at $37^{\circ} \mathrm{C}$ under $5 \% \mathrm{CO}_{2}$ incubation conditions. MTT [3-(4,5-dimethylthiazol-2-yl)-2,5-diphenyltetrazolium bromide reagent (Sigma-Aldrich, St. Louis, MO) was added to the cells for $4 \mathrm{hrs}$. and the assay conducted as previously described in detail [14].

\section{Alkaline phosphatase assay}

This assay (ALP) was used as an indicator of osteoblastic cell differentiation and conducted with slight modifications of previously published techniques [14]. After incubation of the cells under the various conditions described above, the media in each of the wells was removed and replaced with $100 \mu \mathrm{L}$ of $1 \%$ Triton before the culture plate was incubated at $4^{\circ} \mathrm{C}$ for one hour. After a brief centrifugation of the fluid from each of the wells and transfer to fresh wells, $50 \mu \mathrm{L}$ of alkaline buffer (2-amino-2-methyl-1-propanol buffer) (SigmaAldrich, St, Louis MO) was added to each well followed by $50 \mu \mathrm{L}$ of substrate (p-nitro phenol phosphate) (Sigma-Aldrich, St. Louis, MO). The culture plate was incubated for one hour and then absorbance was read at a wavelength of $405 \mathrm{~nm}$ in a standard microplate spectrophotometric reader.

\section{Mineralization assay}

Mineralization was measured with the Alizarin red assay to colorimetrically assess the calcium mineral content associated with the cell cultures using a modified protocol of Gregory, et al. [15]. Cell cultures were washed with phosphate-buffered saline (PBS) and fixed with cold $70 \%$ ethanol for a one-hour period. The samples were rinsed with highly purified water followed by the addition of $40 \mathrm{mM}$ Alizarin red S (ARS), at pH 4.2. After absorption of the dye was complete, the samples were washed 5 times with nanopure water and once with PBS. They were then stored at $-20^{\circ} \mathrm{C}$ prior to dye extraction with cetylpyridinium chloride (CPC), (10\% w/v of sodium phosphate, $\mathrm{pH}$ 7.0). The samples were incubated at room temperature with gentle shaking for 1 hour and absorbance of the CPC extractions was measured at $550 \mathrm{~nm}$ using a standard microplate spectrophotometric reader.

\section{Results}

\section{MTT studies}

As shown in Figure 1, there was a statistically significant increase in osteoblastic cellular activity measured with the MTT assay in cells cultured for 48 hrs on the HeliPLUG ${ }^{\star}$ collagen discs coated with nCS compared to the other groups. Although there was an indication of an increase in activity in the cells grown on the collagen only discs compared to the controls, this effect was not statistically significant under the conditions tested.

The data in Table 1 show that a slight enhancement of osteoblastic cell activity was also obtained when cells were cultured with the $\mathrm{RCM}^{\mathrm{TM}}$ collagen membrane coated with nCS compared to that membrane alone. However, no significant effects on this parameter were seen under the same incubation conditions (48hrs) with the BioGide ${ }^{ø}$ membrane.

\section{Alkaline phosphatase studies}

The alkaline phosphatase activity studies support the concept that collagen together with CS increases the differentiation of osteoblastic 
MTT Assay: 48 Hours

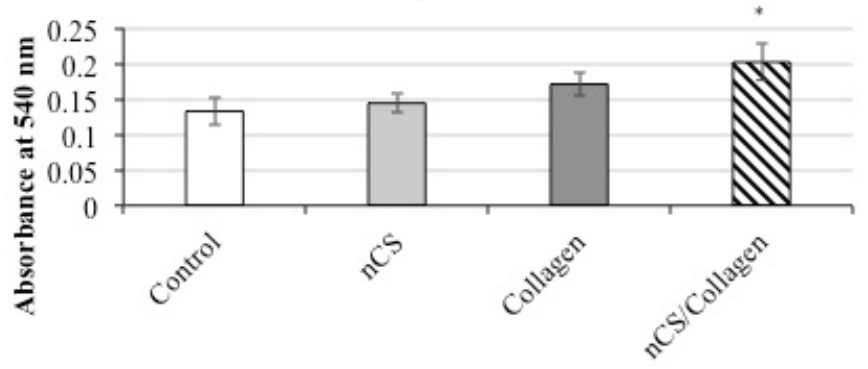

MTT activity in the nCS+Collagen group was higher than that of the control and nCS and Collagen alone groups; Values are the mean absorbance \pm standard deviation * indicates a significant increase in nCS + Collagen group compared with the other groups. $\mathrm{n}=4 ; P<0.05$ ANOVA.

Figure 1. MTT assay: HeliPLUG ${ }^{\circledR}$ collagen material.

Table 1. MTT cell activity studies with different collagen membranes.

\begin{tabular}{|c|c|}
\hline Experiment 1 & Mean absorbance \pm Std. Dev. \\
\hline BioGide ${ }^{\circledR}$ unmodified & $0.39 \pm 0.04$ \\
\hline nCS & $0.45 \pm 0.04$ \\
\hline BioGide ${ }^{\circledR}+$ nCS & $0.41 \pm 0.09$ \\
\hline Experiment 2 & \\
\hline RCM6 $^{\mathrm{TM}}$ unmodified & $0.30 \pm 0.19$ \\
\hline nCS & $0.31 \pm 0.07$ \\
\hline RCM6 ${ }^{\mathrm{TM}}+$ nCS & $0.37 \pm 0.15 * *$ \\
\hline
\end{tabular}

MTT activity as an assessment of cell activity was measured in cells cultured for $48 \mathrm{hrs}$ in the presence of either type of membrane unmodified, nCS material or nCS + membrane modification. Values are the mean absorbance \pm standard deviation. **indicates a significant increase in $\mathrm{nCS}+$ membrane group compared to the other groups; ANOVA; $P<0.05 ; \mathrm{n}=10$ samples per group.

cells. As shown in Figure 2, although in the presence of nCS alone, the levels of this differentiation marker decreased slightly compared to controls, when added in conjunction with the collagen scaffold (HeliPLUG ${ }^{\circledR}$ ), there was a statistically significant increase in this parameter compared to controls as well as the other two treatment groups.

The data in Table 2 show that similar results were obtained when alkaline phosphatase activity was measured in osteoblastic cells cultured with collagen membranes, BioGide ${ }^{\infty}$ and RCM6 $6^{\mathrm{TM}}$. Modification of both types of collagen membranes with nCS in a similar manner as with the HeliPLUG ${ }^{\circ}$ collagen material significantly increased the levels of alkaline phosphatase compared to the unmodified commercially available membranes.

\section{Mineralization studies}

The study shown in Figure 3 further supports the concept that nCS in combination with collagen will lead to enhanced osteoblastic cell activity as manifested in increased mineralization, usually viewed as an end stage in the osteogenesis process. While both nCS and collagen only gave increased mineralization compared to controls, the combination of collagen $+\mathrm{nCS}$ gave significantly greater responses of this parameter.

\section{Discussion}

The nCS coating on collagen membranes yielded results that suggest that the combined use of these materials can have beneficial effects to support osteogenesis at sites where bone regeneration is desired. Calcium sulfate has been used in medicine and dentistry for more than 100 years and has been proven to be a biocompatible material [3]. It has been extensively studied in numerous animal models and has been shown to allow bone tissue growth in osseous defects [6] with timely resorption of the calcium sulfate $[3,16]$. When used as a bone graft, calcium sulfate has been shown to result in new bone formation in human extraction sockets after 3 months [17]. Calcium sulfate has also described as an effective physical barrier during GBR procedures $[5,6]$.

Most recently, the nanosized calcium sulfate product, nCS, used in this present study was shown to be an effective material to support in vivo bone regeneration in a canine model of critical mandibular defects [11]. The rationale for coating collagen membranes with nCS is based on characterization of this material as one with higher surface area and superior mechanical strength than the traditional calcium sulfate [12].

Table 2. Alkaline phosphatase activity studies with different collagen membranes.

\begin{tabular}{|c|c|}
\hline Experiment 1 & Mean absorbance \pm Std. Dev. \\
\hline BioGide ${ }^{\circledR}$ unmodified & $0.39 \pm 0.12$ \\
\hline nCS & $0.56 \pm 0.16$ \\
\hline BioGide ${ }^{\circledR}+$ nCS & $0.71 \pm 0.16^{* *}$ \\
\hline Experiment 2 & $0.55 \pm 0.21$ \\
\hline RCM $^{\mathrm{TM}}$ unmodified & $0.61 \pm 0.22$ \\
\hline nCS & $0.75 \pm 0.22 * *$ \\
\hline RCM $^{\mathrm{TM}}+\mathrm{nCS}$ & \\
\hline
\end{tabular}

Alkaline phosphatase activity was measured in cells cultured for $96 \mathrm{hrs}$ in the presence of either type of membrane unmodified, nCS material or nCS+membrane modification. Values are the mean absorbance \pm standard deviation. $* *$ indicates a significant increase in $\mathrm{nCS}+$ membrane group compared to the other groups; ANOVA; $P<0.05 ; \mathrm{n}=10$ samples per group.

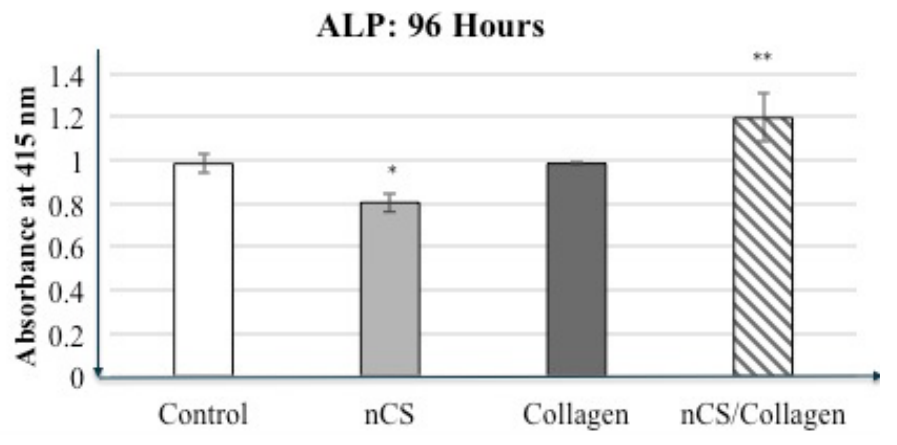

Alkaline phosphatase (ALP) activity in the nCS+Collagen group was higher than that in the control group (cells only in culture well) as well as nCS and Collagen alone groups Values are the mean absorbance + standard deviation; * indicates a difference compared to controls at $P<0.05$. ** indicates a significant increase in ALP activity when comparing nCS + Collagen with the other groups. $P<0.05$ ANOVA; $\mathrm{n}=4$ in all groups.

Figure 2. Alkaline phosphatase assay- HeliPLUG® collagen material.

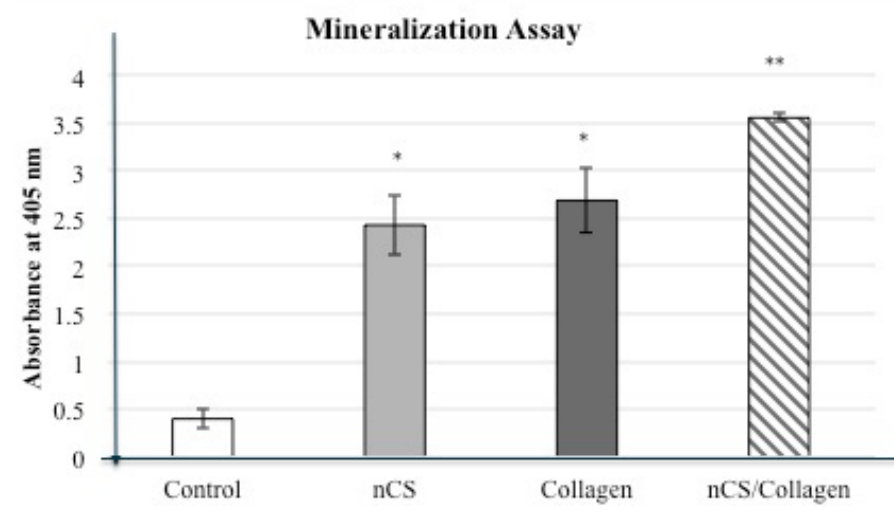

Cells were incubated for 21 days with the indicated materials. Mineralization activity in the $\mathrm{nCS}+\mathrm{Collagen}$ group was approximately 7 -fold higher than that in the control group. Values are the mean absorbance \pm standard deviation; * indicates a significant increase compared to control $P<0.05$. $* *$ indicates a significant increase in mineralization when comparing nCS + Collagen with the other groups. $P<0.05$ (ANOVA); $\mathrm{n}=4$ in all groups.

Figure 3. Mineralization assay: HeliPLUG ${ }^{\circledR}$ collagen material. 
The in vitro studies conducted here support the concept that the nCS coating of collagen membranes commonly as a barrier in GTR can enhance the activity of the bone forming osteoblastic cell populations. Since collagen type $\mathrm{I}$ is the major organic component of bone extracellular material and is produced and secreted by osteoblastic cells during the process of osteogenesis, membranes made primarily of this material provide a biomimetic environment to support the bone formative processes. In this regard, osteoblastic cell activity was measured with assays that measure mitochondrial activity (MTT) as well as alkaline phosphatase that is an early marker for osteoblastic cell differentiation. Mineralization, a late marker of osteoblastic activity, was also assessed in an experiment with one of the three collagen products tested.

There are a number of different collagen membranes presently available for clinical use. These various products exhibit different resorption times and are often chosen for a particular procedure because of this property with more durable membranes with longer resorption times used for guided bone regeneration and those with shorter resorption periods used for procedures such as control of bleeding [18]. These different properties can be due to differences in the collagenous fiber orientation as well as the use of different collagen types. With respect to the collagen products used in this present study, the HeliPLUG ${ }^{\circledast}$ product has been reported to have resorption in the range of 10-14 days in vivo whereas the two other products, $\mathrm{RCM}^{\mathrm{TM}}$ and BioGide ${ }^{\circ}$, have been reported to have resorption periods in the range of 26-38 weeks and 24 weeks, respectively [19]. Since the experiments conducted in the present study were in vitro ones of relatively short duration, the resorption of the various membranes did not most likely factor into the results with respect to the enhancing effects of the nCS.

However, our data are consistent with those of others that suggest that collagen membranes can support the growth/proliferation of these cells $[20,21]$. It is interesting to note that the nCS coating did not significantly increase this parameter as measured with the MTT assay for the BioGide ${ }^{\star}$ membrane and had only relatively small effects for the $\mathrm{RCM}^{\mathrm{TM}}$ and HeliPLUG ${ }^{\circ}$ products. In another in vitro study testing six different GTR membranes, it was found that bioabsorbable membranes stimulate osteoblastic cell proliferation more than nonresorbable ones and that there are also differences among the collagen ones tested with BioGide ${ }^{\star}$ showing relatively less proliferative ability [22]. It was suggested that differences in topography of the surfaces of the membranes and other differences such as pore size may account for different effects of cell proliferation as well as differences in the dissolution of the membrane material [22]. These types of differences might also be responsible for the differences in the cell activity with the collagen membranes measured by MTT responses noted in our present study as well. With all three collagen membranes tested here, however, the effects of the nCS were significant for the enhancement of the differentiation parameter, alkaline phosphatase. It is possible that release of calcium ions from the nCS coating into the local microenvironment of the osteoblastic cell cultures could promote osteogenic activity as proposed by Orsini, et al. [23] for calcium sulfate particles used in a preclinical animal model. This release of calcium from nCS could be particularly important in the enhanced mineralization observed in our cultures with both nCS alone and with the collagen material.

\section{Conclusion}

The experiments described in this paper provide evidence that nCS is a biocompatible material which has the potential with a bioresorbable collagen membrane to improve human osteoblastic cell activity. In vivo, there will be additional bioprocesses such as increased angiogenesis that might be stimulated by the combined use of these products at sites where bone regeneration is desired but the present in vitro studies suggest that direct effects on osteoblastic cell activity can be involved in the overall regenerative effect.

\section{References}

1. Dahlin C, Linde A, Gottlow J, Nyman S (1988) Healing of bone defects by guided tissue regeneration. Plast Reconstr Surg 81: 672-676. [Crossref]

2. Rakhmatia YD, Ayukawa Y, Furuhashi A, Koyano K (2013) Current barrier membranes: titanium mesh and other membranes for guided bone regeneration in dental applications. J Prosthodont Res 31: 3-14. [Crossref]

3. Peltier LF, Bickel EY, Lillo R, Thein MS (1957) The use of plaster of paris to fill defects in bone. Ann Surg 146: 61-69. [Crossref]

4. Walsh WR, Morberg P, Yu Y, Yang JL, Haggard W, et al. (2003) Response of a calcium sulfate bone graft substitute in a confined cancellous defect. Clin Orthop Relat Res 406 228-236. [Crossref]

5. Sottosanti JS (1997) Calcium sulfate: a valuable addition to the implant/bone regeneration complex. Dent Implantol Update 8: 25-29. [Crossref]

6. Pecora G, Andreana S, Margarone JE 3rd, Covani U, Sottosanti JS (1997) Bone regeneration with a calcium sulfate barrier. Oral Surg Oral Med Oral Pathol Oral Radiol Endod 84: 424-429. [Crossref]

7. Turri A, Dahlin C (2015) Comparative maxillary bone-defect healing by calciumsulphate or deproteinized bovine bone particles and extra cellular matrix membranes in a guided bone regeneration setting: an experimental study in rabbits. Clin Oral Implants Res 26: 501-506. [Crossref]

8. Webster TJ, Ergun C, Doremus RH, Siegel RW, Bizios R (2000) Enhanced functions of osteoblasts on nanophase ceramics. Biomaterials 21: 1803-1810. [Crossref]

9. Chris Arts JJ, Verdonschot N, Schreurs BW, Buma P (2006) The use of a bioresorbable nano-crystalline hydroxyapatite paste in acetabular bone impaction grafting. Biomaterials 27: 1110-1118. [Crossref]

10. Schwarz F, Bieling K, Latz T, Nuesry E, Becker J (2006) Healing of intrabony periimplantitis defects following application of a nanocrystalline hydroxyapatite (Ostim) or a bovine-derived xenograft (Bio-Oss) in combination with a collagen membrane (Bio-Gide). A case series. J Clin Periodontol 33: 491-499. [Crossref]

11. Khobragade P, Jain A, Setlur Nagesh SV, Andreana S, Dziak R, Sunkara SK, et al. (2015) Micro-computed tomography (CT) based assessment of dental regenerative therapy in the canine mandible model. In SPIE Medical Imaging, International Society for Optics and Photonics, 94171D-94171D.

12. Park YB, Mohan K, Al-Sanousi A, Almaghrabi B, Genco RJ, et al. (2011) Synthesis and characterization of nanocrystalline calcium sulfate for use in osseous regeneration. Biomed Mater 6: 055007. [Crossref]

13. Sculean A Nikolidakis D, Schwarz F (2008) Regeneration of periodontal tissues combinations of barrier membranes and grafting materials - biological foundation and preclinical evidence: a systematic review. J Clin Periodontol 35: 106-116. [Crossref]

14. Dziak R, Yang BM, Leung BW, Li S, Marzec N, et al. (2003) Effects of sphingosine1-phosphate and lysophosphatidic acid on human osteoblastic cells. Prostaglandins Leukot Essent Fatty Acids 68: 239-249. [Crossref]

15. Gregory CA, Grady Gunn W, Peister A, Prockop DJ (2004) An Alizarin red-based assay of mineralization by adherent cells in culture: comparison with cetylpyridinium chloride extraction. Anal Biochem 329: 77-84. [Crossref]

16. Maeda ST, Bramane CM, Taga R, Garcia RB, de Moraes IG, et al. (2007) Evaluation of surgical cavities filled with three types of calcium sulfate. J Appl Oral Sci 15: 416419. [Crossref]

17. Guarnieri R, Pecora G, Fini M, Aldini NN, Giardino R, Orsini G, et al. (2004) Medical grade calcium sulfate hemihydrate in healing of human extraction sockets: clinical and histological observations at 3 months. J Periodontol 75: 902-908. [Crossref]

18. Bunyaratavej P, Wang HL (2001) Collagen membranes: a review. J Periodontol 72 215-229. [Crossref]

19. Almazrooa SA, Noonan V, Woo SB (2014) Resorbable collagen membranes: histopathologic features. Oral Surg Oral Med Oral Pathol Oral Radiol 118: 236240. [Crossref] 
20. Rothamel D, Schwarz F, Sculean A, Herten M, Scherbaum W, et al. (2004) Biocompatibility of various collagen membranes in cultures of human PDL fibroblasts and human osteoblast-like cells. Clin Oral Implants Res 15: 443-449. [Crossref]

21. Alpar B, Leyhausen G, Gunay H, Geurtsen W (2000) Compatibility of resorbable and nonresorbable guided tissue regeneration membranes in cultures of primary human periodontal ligament fibroblasts and human osteoblast-like cells. Clin Oral Investig 4 : 219-225. [Crossref]
22. Kasaj A, Reichert C, Götz H, Röhrig B, Smeets R, Willershausen B (2008) In vitro evaluation of various bioabsorbable and nonresorbable barrier membranes for guided tissue regeneration. Head Face Med 4: 1-8. [Crossref]

23. Orsini G, Ricci J, Scarano A, Pecora G, Petrone G, Lezzi A, et al. (2004) Bone defect healing with calcium-sulfate particles and cement: an experimental study in rabbit. $J$ Biomed Mater Res B Appl Biomater 68: 199-208. [Crossref]

Copyright: $(02017$ Laurel T. This is an open-access article distributed under the terms of the Creative Commons Attribution License, which permits unrestricted use, distribution, and reproduction in any medium, provided the original author and source are credited. 